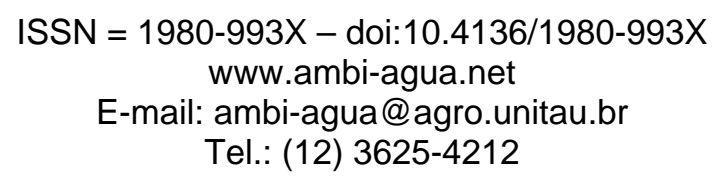

\title{
Colonization of leaf litter of two aquatic macrophytes, Mayaca fluviatilis Aublet and Salvinia auriculata Aublet by aquatic macroinvertebrates in a tropical reservoir
} (doi:10.4136/ambi-agua.171)

\author{
Fabio Laurindo da Silva ${ }^{1}$; Heliana Rosely Neves Oliveira²; Suzana Cunha Escarpinati ${ }^{3}$; \\ Alaide Aparecida Fonseca-Gessner ${ }^{1}$; Marcia Cristina de Paula ${ }^{1}$ \\ ${ }^{1}$ Universidade Federal de São Carlos - UFSCar, Depart. de Hidrobiologia, Laboratório de Entomologia Aquática \\ E-mail: fabelha@hotmail.com; gessner@power.ufscar.br; marciacdp@ig.com.br \\ ${ }^{2}$ Fundação de Medicina Tropical do Amazonas, Gerência de Entomologia \\ E-mail: helianaoli@yahoo.com.br \\ ${ }^{3}$ Universidade Federal da Grande Dourados - UFGD, Faculdade de Ciências Biológicas e Ambientais \\ E-mail: scescarpinati@yahoo.com.br
}

\begin{abstract}
Decomposition and colonization of S. auriculata and M. fluviatilis by macroinvertebrates were analyzed during 40 days to determine whether differences existed on colonization by aquatic macroinvertebrates of two macrophytes with distinct habits (submerged versus fluctuant). Leaf litter of $S$. auriculata and M. fluviatilis were incubated in 24 litter bags (12 of each species), in a small reservoir surrounded by a cerrado fragment with low level of anthropic impact. After 10, 20, 30 and 40 days, the litter bags were removed and aquatic macroinvertebrates community was analyzed. Two hundred twenty macroinvertebrates were associated with $S$. auriculata and 261 were associated with $M$. fluviatilis, identified in 24 taxa. Both macrophyte species were colonized mainly by macroinvertebrate predators. Ablabesmyia with predator and collector food mechanisms was present in all sampling. The data showed an expressive increase of abundance during the process of decomposition and a decrease at the end of the experiment, in both macrophytes. Cluster analysis permitted inference that the colonization of the leaf liter by macroinvertebrates was determinated by incubation time of leaf litter not by the habit of macrophytes (submerged or fluctuant).
\end{abstract}

Keywords: hydrophyte; colonization; leaf litter; lentic systems.

\section{Colonização de detritos foliares de duas macrófitas aquáticas, Salvinia auriculata Aublet e Mayaca fluviatilis Aublet, por macroinvertebrados aquáticos em um reservatório tropical}

\section{RESUMO}

A decomposição e colonização de Salvinia auriculata e Mayaca fluviatilis por macroinvertebrados foi analisada por um período máximo de 40 dias para determinar se há diferenças entre a colonização por macroinvertebrados aquáticos de duas espécies de macrófitas com hábitos distintos (submersa versus flutuante). Detritos foliares de $S$. auriculata e $M$. fluviatilis foram incubados em 24 bolsas (12 de cada espécie) em um pequeno reservatório circundado por um fragmento de cerrado com reduzido nível de impacto antrópico. Após 10, 20, 30 e 40 dias, as bolsas foram removidas e a comunidade de macroinvertebrados aquáticos foi analisada. Foi constatado um total de 220 macroinvertebrados associados à $S$. auriculata e 261 associados à $M$. fluviatilis, identificados em 24 táxons. Ambas as espécies de macrófitas foram colonizadas principalmente por

Revista Ambiente \& Água - An Interdisciplinary Journal of Applied Science: v. 6, n. 1, 2011. 
SILVA, F. L.; OLIVEIRA, H. R. N.; ESCARPINATI, S. C.; FONSECA-GESSNER, A. A.; PAULA, M. C. Colonization of leaf litter of two aquatic macrophytes, Mayaca fluviatilis, Aublet and Salvinia auriculata, Aublet by aquatic macroinvertebrates in a tropical reservoir. Ambi-Agua, Taubaté, v. 6, n. 1, p. 30-39, 2011. (doi:10.4136/ambi-agua.171)

macroinvertebrados predadores. Ablabesmyia com mecanismo para predação e coleta esteve presente em todas as amostras. Os dados mostraram um aumento expressivo de abundância durante o processo de decomposição e decréscimo ao final do experimento, em ambas as macrófitas. A análise de agrupamento permitiu inferir que a colonização dos detritos foliares das macrófitas por macroinvertebrados foi determinada pelo tempo de incubação e não pelo hábito da macrófita (submersa ou flutuante).

Palavras-chave: hidrófita; colonização; detritos foliares; sistemas lênticos.

\section{INTRODUCTION}

The importance of the aquatic macrophytes as a habitat of permanence for aquatic animals has been widely recognized and emphasized by numerous authors (Kurashov et al., 1996; Stripari and Henry, 2002; Moretti et al., 2003, Mormul et al., 2006). This type of vegetation constitutes a particular habitat for several aquatic invertebrates. The animal population studies of aquatic habitats usually include at least some reference to the animals associated with vegetation (Dornfeld and Fonseca-Gessner, 2005).

Aquatic macrophytes frequently constitute a substrate for aquatic macroinvertebrates, since they offer protection against predators, serve as a food resource directly (vegetal tissues) and indirectly (substrate for development of perifitic community) (Ward, 1992; Allan, 1995), are a location of oviposition and emergence of several aquatic insects, and they act as filters by maintaining organic particles that can be utilized by detritivorous organisms (TrivinhoStrixino and Strixino, 1993; Trivinho-Strixino et al., 2000).

Aquatic macrophytes decomposition depends on the intrinsic characteristics of the aquatic system, such as the nature of the system bed, water flow, $\mathrm{pH}$ value, water temperature, chemical composition of litter (Wright and Covich, 2005; Leroy and Marks, 2006), and composition of aquatic invertebrates fauna (Graça, 2001). The role of the aquatic macroinvertebrates in the leaf litter decomposition process is not completely clear, however the interest in this process has received growing attention (Gonçalves Jr. et al., 2006; Mormul et al., 2006; Janke and Trivinho-Strixino, 2007).

In this context, the main objective of this study is to evaluate whether there are or not differences between the aquatic macroinvertebrates colonization of two macrophytes with different life histories (submerged and fluctuant habits).

\subsection{Study area}

The experiment was conducted at Fazzari reservoir $\left(21^{\circ} 59^{\prime} \mathrm{S}\right.$ and $47^{\circ} 52^{\prime} \mathrm{W}$ ) located in a preserved area of typical Cerrado vegetation in the São Carlos municipality, São Paulo State, Brazil (Figure 1).

The Fazzari Reservoir is situated in a built-up area in the campus of the Federal University of São Carlos (UFSCar). The reservoir was formed by the damming of a stream of the same name, which spring is located approximately $500 \mathrm{~m}$ upstream, whence it runs through and is protected by gallery forest. This system presented medium levels of dissolved oxygen (6.45 mg. $\left.\mathrm{L}^{-1}\right)$, low electrical conductivity $\left(6 \mu \mathrm{S} . \mathrm{cm}^{-1}\right)$, acid water (pH value 5.47$)$, thermal amplitude varying from $19^{\circ} \mathrm{C}$ to $23^{\circ} \mathrm{C}$ and sandy bed (Fusari and Fonseca-Gessner, 2006). 
SILVA, F. L.; OLIVEIRA, H. R. N.; ESCARPINATI, S. C.; FONSECA-GESSNER, A. A.; PAULA, M. C. Colonization of leaf litter of two aquatic macrophytes, Mayaca fluviatilis, Aublet and Salvinia auriculata, Aublet by aquatic macroinvertebrates in a tropical reservoir. Ambi-Agua, Taubaté, v. 6, n. 1, p. 30-39, 2011. (doi:10.4136/ambi-agua.171)

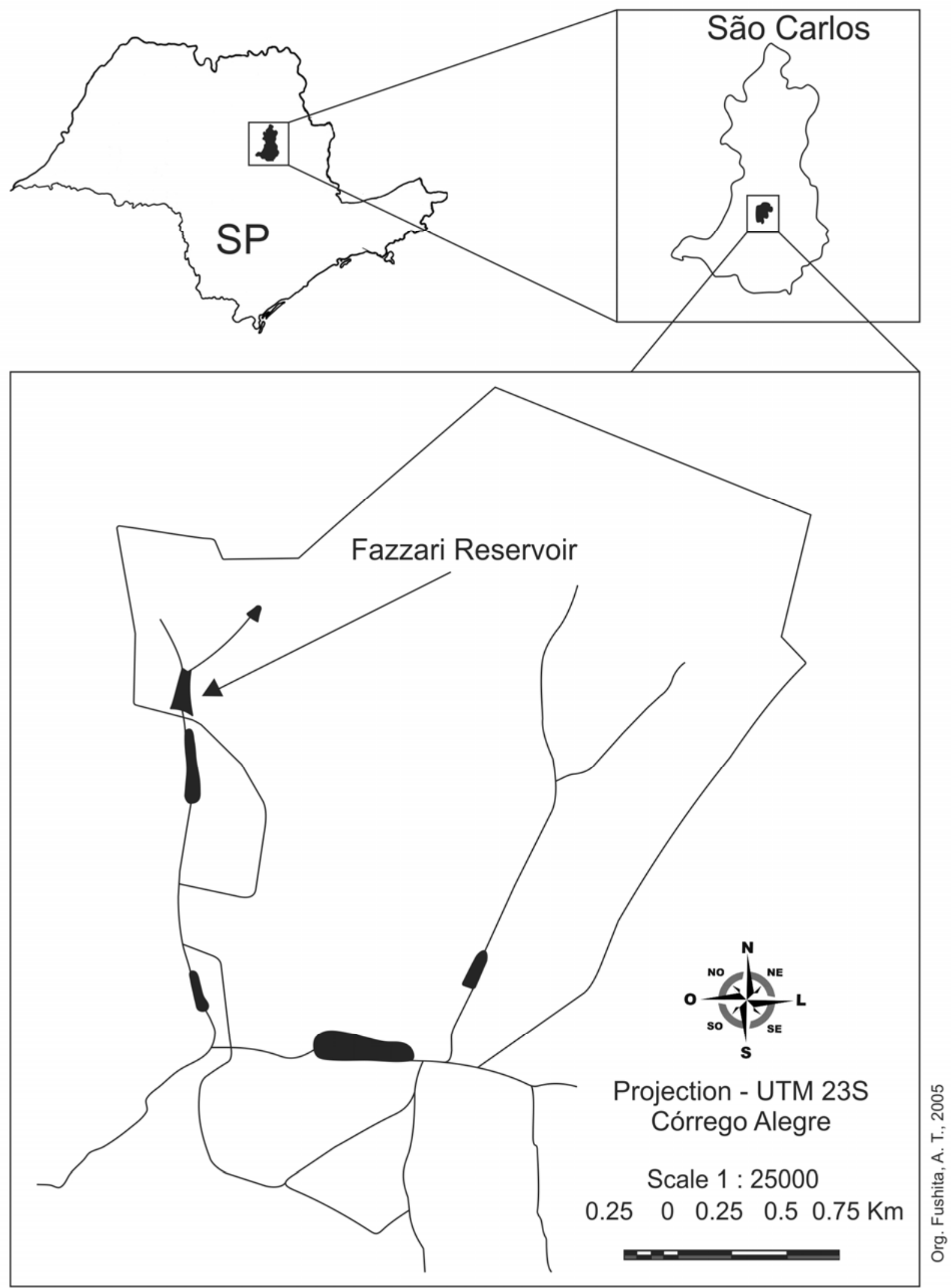

Figure 1. Location of study area: Fazzari Reservoir, within the campus of UFSCar, São Carlos, SP, Brazil. 
SILVA, F. L.; OLIVEIRA, H. R. N.; ESCARPINATI, S. C.; FONSECA-GESSNER, A. A.; PAULA, M. C. Colonization of leaf litter of two aquatic macrophytes, Mayaca fluviatilis, Aublet and Salvinia auriculata, Aublet by aquatic macroinvertebrates in a tropical reservoir. Ambi-Agua, Taubaté, v. 6, n. 1, p. 30-39, 2011. (doi:10.4136/ambi-agua.171)

\section{MATERIAL AND METHODS}

This experiment was conducted during the summer of November and December of 2007. We selected two macrophytes with distinct life habits, following classification of Joly, (1998), fluctuant Salvinia auriculata Aublet and submerged Mayaca fluviatilis Aublet, representatives of aquatic vegetation of study area. Samples of leaves and roots of each macrophyte specie were collected dried at room temperature. The experimental colonization by aquatic macroinvertebrates was conducted by using litter bags of 15 x $20 \mathrm{~cm}$ (Chergui and Patee, 1988; Moretti et al., 2007) and $0.8 \mathrm{~cm}$ of mesh, each one containing $15 \mathrm{~g}$ of dried leaves and roots. Twelve bags of each treatment (24 samples) were randomly placed in the reservoir at a depth of $1 \mathrm{~m}$, where they were left to incubate for 10, 20, 30 and 40 days. At each sampling date, three litter bags of each treatment were randomly collected and treated as a single sample. The contents of each bag were washed through a $0.21 \mathrm{~mm}$ mesh sieve to extract the macroinvertebrates, which were fixed in ethanol $70 \%$ and identified by specific literature and keys (e.g., Brinkhurst and Marchese, 1989; Trivinho-Strixino and Strixino, 1995a; Merrit and Cummins, 1996; Fernandez and Dominguez, 2001). Litter remaining was oven-dried for 48 hours at $60^{\circ} \mathrm{C}$ and weighed to calculate the biomass.

The macroinvertebrate community was characterized according to the following variables: total number of individuals, relative abundance of each taxon in each type of macrophyte and period, and classification as functional feeding groups (Cummins et al., 2005; Merritt and Cummins, 1996), gathering-collectors, filtering-collectors, predators, scrapers and shredders. Differences between absolute abundances of taxa and richness in two macrophyte species were established through the analysis of variance (ANOVA), using as repeated measures the absolute abundance and richness of the macroinvertebrates in each incubation periods. Number of individuals of macroinvertebrates in the two macrophytes were compared by quantitative cluster analyses, using the unweighted pair-group method with arithmetic averages (UPGMA).

\section{RESULTS AND DISCUSSION}

At end of experimental period, 481 individuals were collected, belonging to 24 taxa of macroinvertebrates (Table 1). Samples of S. auriculata resulted in 220 associated organisms, while $M$. fluviatilis samples resulted in 261. In relation to species richness, the detritus of $M$. fluviatilis showed the highest number of taxa after 20 days of exposure, while the detritus of S. auriculata showed the highest richness after 30 days of exposure (Figure 2). In both macrophytes, the taxa richness and total abundance showed a decrease in 40 days de exposure.

The colonization of aquatic macrophytes by macroinvertebrates may be limited by the biology of organisms and architecture of structures as leaves and stems. Such aspects contribute to the creation of different microhabitats, which favor the occurrence of certain macroinvertebrates in elevated density (Humpries, 1996).

In this study were collected a high number of insects (417), representing $86 \%$ of the colonist macroinvertebrates in both aquatic macrophytes. This result can be associated with the fact that vegetation in aquatic ecosystems provides great survival conditions, since it offers opportunities for shelter against predators, a site of oviposition, and diversification of food resources, and functions as a filter retaining particulate organics that can be used by the detritivorous (Trivinho-Strixino and Strixino, 1993; Trivinho-Strixino et al., 2000).

Ablabesmyia, with predator and collector food mechanisms, was present in all samplings of both plant substrates. Collectors followed. The prevalence of Ablabesmyia may be explained by the experimental design since the litter bags were installed along the margins of the reservoir where they may have acted as litering nets, filtering the detritus originating at the 
SILVA, F. L.; OLIVEIRA, H. R. N.; ESCARPINATI, S. C.; FONSECA-GESSNER, A. A.; PAULA, M. C. Colonization of leaf litter of two aquatic macrophytes, Mayaca fluviatilis, Aublet and Salvinia auriculata, Aublet by aquatic macroinvertebrates in a tropical reservoir. Ambi-Agua, Taubaté, v. 6, n. 1, p. 30-39, 2011. (doi:10.4136/ambi-agua.171)

margins. This hypothesis, which is supported by Trivinho-Strixino et al. (2000) and Mormul et al. (2006), argues that the accumulation of debris in aquatic macrophytes contributes significantly to number of collectors present, which are potential prey for predators. The collectors were found in high abundance in all observations. This result probably occurred because of the large amount of particulate matter, which it is an indicative of prevalence of a detritivorous food chain in the macrophytes (Trivinho-Strixino et al., 2000).

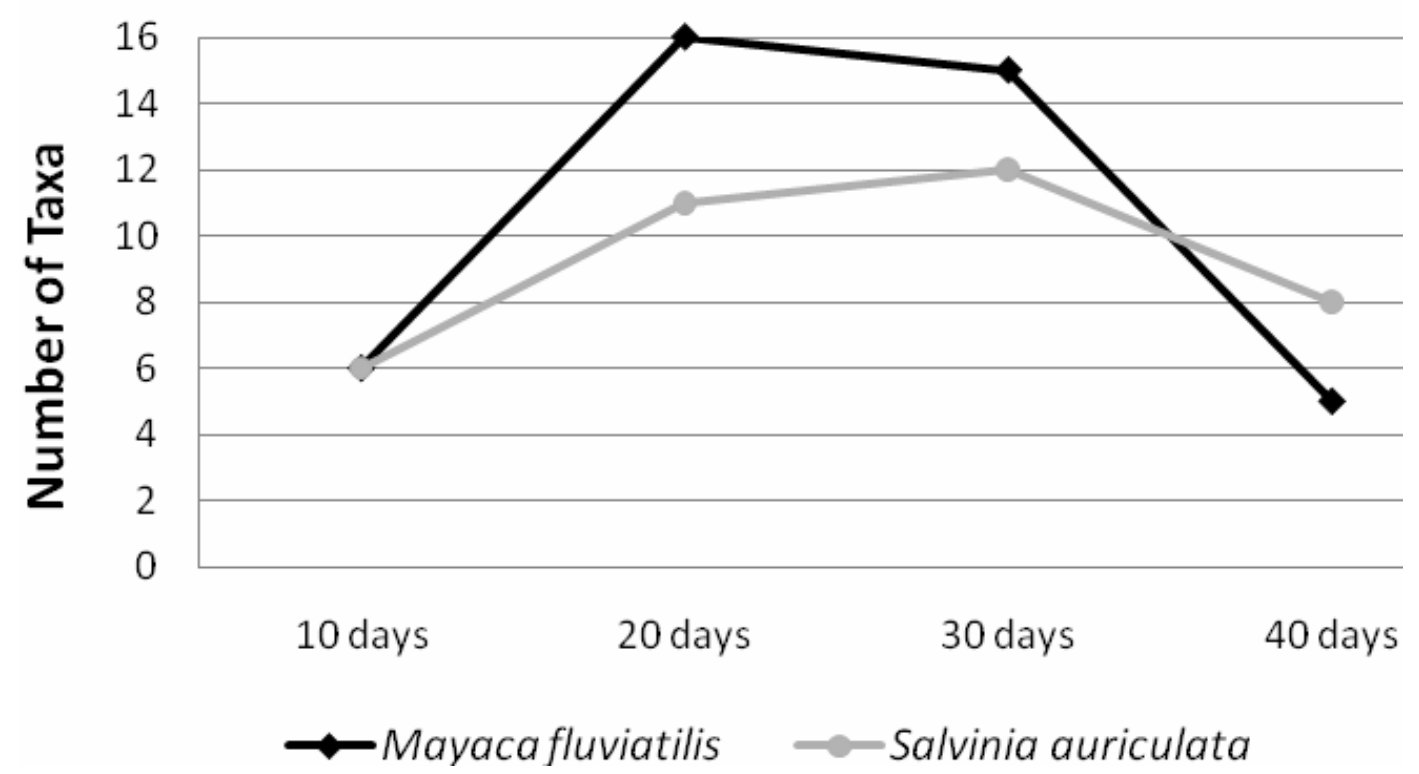

Figure 2. Richness of aquatic macroinvertebrates (by litter bag sample), during decomposition process associated with $S$. auriculata and $M$. fluviatilis at Fazzari Reservoir.

The live aquatic macrophytes are not a good food resource for the majority of the members of aquatic macroinvertebrates community, since they are difficult to digest (Trivinho-Strixino and Strixino, 1995b). According to the same authors, during the decomposition process, bacteria and fungi produce an increase in nitrogen and protein, and the detritus becomes attractive as food source of the invertebrates. Therefore, a high abundance and decomposition might be expected to occur in the middle of the experimentation time, when the macrophytes still were an attractive resource to macroinvertebrates due to their possible high palatability. In this study, the analysis of the biomass remaning (Figure 3) showed a pronounced difference during the experiment, with elevated dry mass loss during after 30 days of colonization. These results can be attributed to the higher macroinvertebrate abundance and richness registered during this time in both treatments. $M$. fluviatilis did not present a linear pattern of mass loss, exhibiting an unexpected reduction, and consequently, an increase in biomass remaining after 40 days, which can be explained by the strong rains during the period what probably prevented the effective colonization this substrate.

In relation to the temporal colonization process, both macrophytes presented a similar pattern: the highest number of individuals occurred within 30 days of colonization and decayed afterwards. Such fact may be demonstrated by the similarities of the macroinvertebrate abundances in the different experimental periods (Table 1). It is important to consider that the populations present a natural growth rate, which in this case, aquatic macroinivetebrates assemblage, can be considered exponential, since the populations grow as a function of population parameters and as a function size. Therefore it was expected an increase of populations along the time intervals, as recorded this study. The reduction observed after 40 days might be related to decrease quality of the substrate as food resource. 


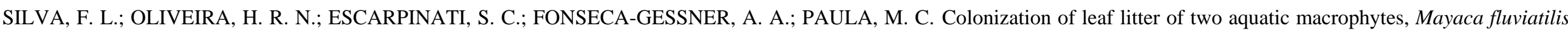
Aublet and Salvinia auriculata, Aublet by aquatic macroinvertebrates in a tropical reservoir. Ambi-Agua, Taubaté, v. 6, n. 1, p. 30-39, 2011. (doi:10.4136/ambi-agua.171)

Table 1. Absolute (N) and relative (ni) abundance of aquatic macroinvertebrates (by litter bag sample) during the decomposition of $S$. auriculata and M. fluviatilis at Fazzari Reservoir. FTG $=$ functional trophic groups, $\mathrm{C}=$ Collector, F $=$ Filterer, $\mathrm{P}=$ Predator, SC $=\mathrm{Scraper}$, SH $=\mathrm{Shredder}$.

\begin{tabular}{|c|c|c|c|c|c|c|c|c|c|c|c|c|c|c|c|c|c|}
\hline \multirow{3}{*}{ Taxa } & \multirow{3}{*}{ FTG } & \multicolumn{4}{|c|}{10 Days } & \multicolumn{4}{|c|}{20 Days } & \multicolumn{4}{|c|}{30 Days } & \multicolumn{4}{|c|}{40 Days } \\
\hline & & \multicolumn{2}{|c|}{$\begin{array}{c}\text { S. } \\
\text { auriculata }\end{array}$} & \multicolumn{2}{|c|}{$\begin{array}{c}\text { M. } \\
\text { fluviatilis }\end{array}$} & \multicolumn{2}{|c|}{$\begin{array}{c}\text { S. } \\
\text { auriculata }\end{array}$} & \multicolumn{2}{|c|}{$\begin{array}{c}M . \\
\text { fluviatilis }\end{array}$} & \multicolumn{2}{|c|}{$\begin{array}{c}\text { S. } \\
\text { auriculata }\end{array}$} & \multicolumn{2}{|c|}{$\begin{array}{c}M . \\
\text { fluviatilis }\end{array}$} & \multicolumn{2}{|c|}{$\begin{array}{c}\text { S. } \\
\text { auriculata }\end{array}$} & \multicolumn{2}{|c|}{$\begin{array}{c}M . \\
\text { fluviatilis }\end{array}$} \\
\hline & & $\mathrm{N}$ & ni & $\mathrm{N}$ & ni & $\mathrm{N}$ & ni & $\mathrm{N}$ & ni & $\mathrm{N}$ & ni & $\mathrm{N}$ & ni & $\mathrm{N}$ & ni & $\mathrm{N}$ & ni \\
\hline \multicolumn{18}{|l|}{ Coleoptera } \\
\hline Hydrophilidae & $\mathrm{C} / \mathrm{P} / \mathrm{S}$ & & & & & 1 & 0.02 & & & & & & & & & & \\
\hline \multicolumn{18}{|l|}{ Diptera } \\
\hline Ceratopogonidae & $\mathrm{P}$ & & & & & 1 & 0.02 & 1 & 0.02 & 2 & 0.02 & 2 & 0.01 & & & & \\
\hline \multicolumn{18}{|l|}{ Chironomidae } \\
\hline Ablabesmyia & $\mathrm{P}$ & 9 & 0.45 & 4 & 0.27 & 13 & 0.20 & 19 & 0.29 & 35 & 0.34 & 44 & 0.28 & 21 & 0.64 & 10 & 0.38 \\
\hline Caladomyia ortoni & $\mathrm{F} / \mathrm{C}$ & & & & & & & & & & & 7 & 0.05 & & & & \\
\hline Caladomyia riotarumensis & $\mathrm{F} / \mathrm{C}$ & & & & & & & 6 & 0.09 & 5 & 0.05 & 7 & 0.05 & 3 & 0.09 & & \\
\hline Cladopelma & $\mathrm{C}$ & & & & & & & 1 & 0.02 & & & & & & & & \\
\hline Chironomus & $\mathrm{C} / \mathrm{SH}$ & & & & & & & & 0.00 & 6 & 0.06 & 13 & 0.08 & 1 & 0.03 & & \\
\hline Endotribelos & $\mathrm{SH}$ & 1 & 0.05 & & & 1 & 0.02 & 2 & 0.03 & 1 & 0.01 & & & & & & \\
\hline Fissimentum & $\mathrm{C}$ & & & & & & & & & & & & & 1 & 0.03 & 1 & 0.04 \\
\hline Fittkauimyia & $\mathrm{P}$ & & & & & & & & & 2 & 0.02 & & & & & & \\
\hline Goeldichironomus & $\mathrm{C}$ & 1 & 0.05 & & & 3 & 0.05 & 5 & 0.08 & 6 & 0.06 & 20 & 0.13 & 4 & 0.12 & 9 & 0.35 \\
\hline Harnischia Complex & $\mathrm{C} / \mathrm{SC}$ & & & & & & & & & 1 & 0.01 & & & & & & \\
\hline Labrundinia & $\mathrm{P}$ & & & & & 2 & 0.03 & 2 & 0.03 & 3 & 0.03 & 1 & 0.01 & 1 & 0.03 & & \\
\hline Polypedilum & $\mathrm{C} / \mathrm{SH}$ & 8 & 0.40 & 4 & 0.27 & 16 & 0.25 & 6 & 0.10 & 36 & 0.35 & 36 & 0.23 & 2 & 0.06 & 2 & 0.08 \\
\hline Tanytarsus & $\mathrm{C} / \mathrm{F} / \mathrm{S}$ & & & & & & & 1 & 0.02 & & & 2 & 0.01 & & & & \\
\hline \multicolumn{18}{|l|}{ Ephemeroptera } \\
\hline Caenidae & $\mathrm{C}$ & & & & & & & 6 & 0.09 & 4 & 0.04 & 4 & 0.03 & & & 4 & 0.15 \\
\hline Polymitarcyidae & $\mathrm{C}$ & & & & & & & & & & & 1 & 0.01 & & & & \\
\hline \multicolumn{18}{|l|}{ Hirudinea } \\
\hline Glossiphoniidae & $\mathrm{P}$ & & & 1 & 0.07 & 13 & 0.20 & 1 & 0.02 & & & & & & & & \\
\hline \multicolumn{18}{|l|}{ Odonata } \\
\hline Lestidae & $\mathrm{P}$ & & & 1 & 0.07 & & & 1 & 0.02 & & & & & & & & \\
\hline \multicolumn{18}{|l|}{ Oligochaeta } \\
\hline Naididae & $\mathrm{C} / \mathrm{P}$ & & & 5 & 0.33 & 5 & 0.08 & 2 & 0.03 & & & & & & & & \\
\hline Tubificidae & $\mathrm{C}$ & 1 & 0.05 & & & 10 & 0.15 & 10 & 0.15 & & & 16 & 0.10 & & & & \\
\hline \multicolumn{18}{|l|}{ Trichoptera } \\
\hline Hydropsychidae & $\mathrm{F}$ & & & & & & & 2 & 0.03 & 1 & 0.01 & 1 & 0.01 & & & & \\
\hline Leptoceridae & $\mathrm{C} / \mathrm{P} / \mathrm{S}$ & & & & & & & & & & & 1 & 0.01 & & & & \\
\hline Total & & 20 & & 15 & & 65 & & 65 & & 102 & & 155 & & 33 & & 26 & \\
\hline
\end{tabular}


SILVA, F. L.; OLIVEIRA, H. R. N.; ESCARPINATI, S. C.; FONSECA-GESSNER, A. A.; PAULA, M. C. Colonization of leaf litter of two aquatic macrophytes, Mayaca fluviatilis, Aublet and Salvinia auriculata, Aublet by aquatic macroinvertebrates in a tropical reservoir. Ambi-Agua, Taubaté, v. 6, n. 1, p. 30-39, 2011. (doi:10.4136/ambi-agua.171)
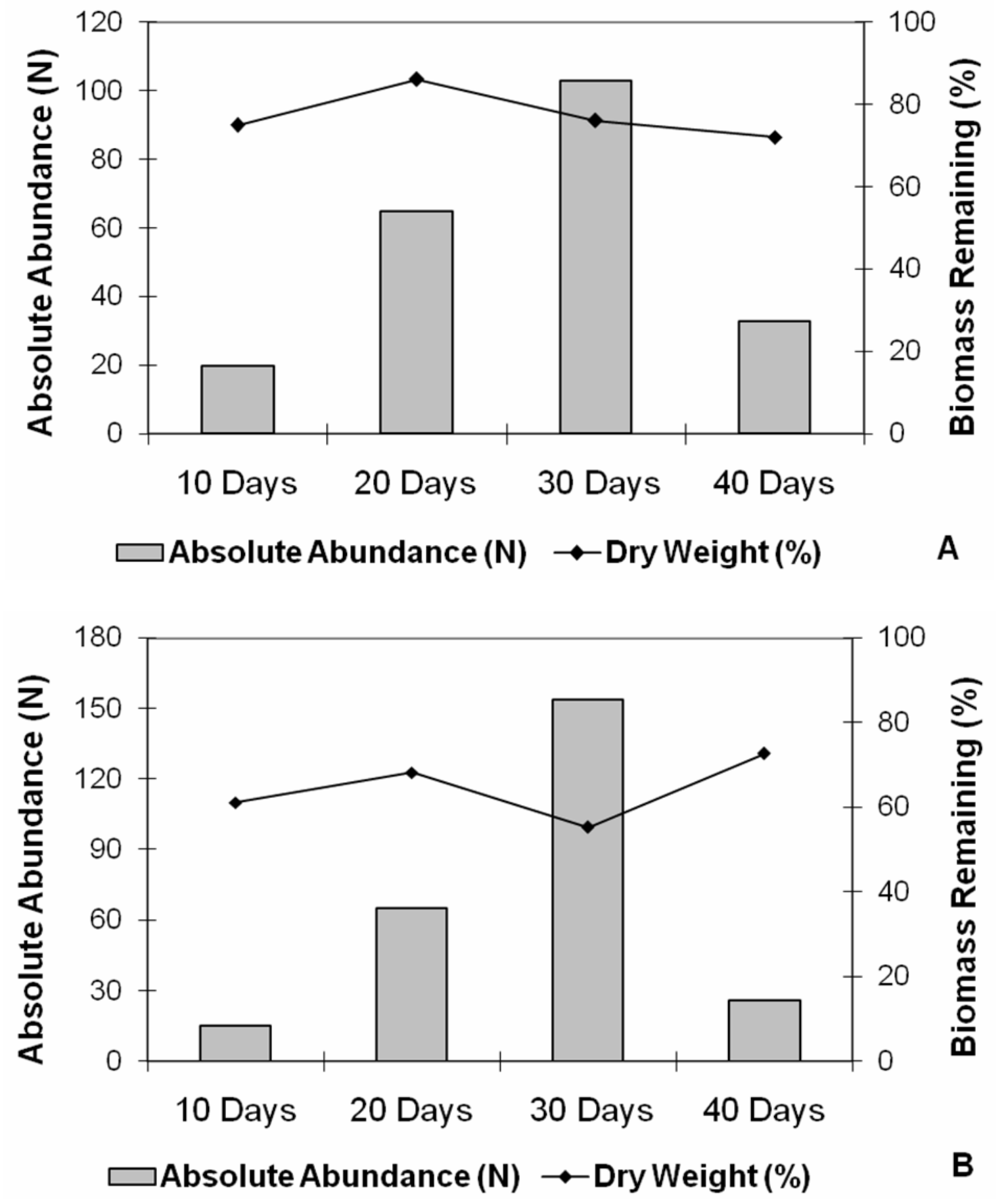

Figure 3. Absolute abundance (by litter bag sample) and leaf mass loss during litter decomposition process associated with S. auriculata (A) and M. fluviatilis (B) at Fazzari Reservoir.

The macroinvertebrate absolute abundances did not show significant differences (ANOVA, $\mathrm{F}_{(1,4)}=0.394 ; \mathrm{p}=0.564$ ) between the treatments (macrophytes). However, there were significant differences (ANOVA, $\mathrm{F}_{(3.12)}=16.350$; $\mathrm{p}<0.001$ ) among different incubation times. Similar results were obtained when was analyzed the richness in two macrophyte. There were no significant differences (ANOVA, $\mathrm{F}_{(1,4)}=0.058 ; \mathrm{p}=0.821$ ) between the treatments, but there were significant differences (ANOVA, $F_{(3.12)}=7.135 ; p=0.005$ ) due to 
SILVA, F. L.; OLIVEIRA, H. R. N.; ESCARPINATI, S. C.; FONSECA-GESSNER, A. A.; PAULA, M. C. Colonization of leaf litter of two aquatic macrophytes, Mayaca fluviatilis, Aublet and Salvinia auriculata, Aublet by aquatic macroinvertebrates in a tropical reservoir. Ambi-Agua, Taubaté, v. 6, n. 1, p. 30-39, 2011. (doi:10.4136/ambi-agua.171)

the incubation times. These results were also confirmed through cluster analysis and indicated that the incubation time is determinant in the colonization of macrophytes by macroinvertebrates.

Cluster analysis, based on the absolute abundance of taxa, revealed the formation of four groups: (1) those represented by litter bags removed with 10 days, showed similarity of 65.3\%; (2) those formed by litter bags removed with 20 days, presented similarity of $63.1 \%$; (3) those formed by litter bags removed with 30 days, presented greater similarity $(73.1 \%)$; and those (4) represented by litter bags removed with 40 days, showed a lower affinity (59.4\%).

Based on the cluster analysis, it was possible to infer that in this experiment the colonization of the leaf liters by aquatic macroinvertebrates was determined by the incubation time of the leaf litter and not by their plant habit (submerged or fluctuant), given that different macrophytes (S. auriculata and M. fluviatilis) showed similar patterns of colonization.

\section{CONCLUSIONS}

The results presented here follow the same pattern observed in other studies with colonization of aquatic macrophytes by aquatic macroinvertebrates (Gonçalves Jr. et al., 2006; Mormul et al., 2006; Janke and Trivinho-Strixino, 2007). Macrophytes newly incubated do not represent a good food resource for a macroinvertebrates assemblage, since they have a reduced palatability and content protein. This pattern reflected an initial period with lower abundance of organisms and a medium period with peak of abundance that decrease afterwards. The data also showed that incubation time of leaf litter is more important than plant habit, given that different macrophytes presented similar patterns of colonization.

We also observed in all substrates and periods the dominance of Ablabesmyia. The larvae pertaining to this genus of Chironomidae are commonly described as predators of others macroinvertebrates and also exhibit collector food mechanisms. Such a fact can be associated with accumulation of debris in aquatic macrophyte, that contribute directly to collector habit and indirectly to predatory habit, there is an increase in of members of the detritivorous chain, which are potential prey for predators. These data confirm the importance of aquatic macrophytes as a biotope for the macroinvertebrate community.

\section{ACKNOWLEDGMENTS}

We thank Susana Trivinho Strixino for suggestions for realization this experiment, Tadeu de Siqueira Barros and Nathan G. Viets for helpful comments. Thanks are also due to Fábio Toshiro T. Hanashiro for aid in the statistical analysis.

\section{REFERENCES}

ALLAN, J. D. Stream ecology: structure and functioning of running waters. Oxford: Chapman \& Hall, 1995. 388 p.

CHERGUI, H.; PATTEE, E. The impact of benthic invertebrates on the breakdown of poplar leaves in the network of a large European river. Archives of Hydrobilogy, v. 113, p. 15-25, 1988. 
SILVA, F. L.; OLIVEIRA, H. R. N.; ESCARPINATI, S. C.; FONSECA-GESSNER, A. A.; PAULA, M. C. Colonization of leaf litter of two aquatic macrophytes, Mayaca fluviatilis, Aublet and Salvinia auriculata, Aublet by aquatic macroinvertebrates in a tropical reservoir. Ambi-Agua, Taubaté, v. 6, n. 1, p. 30-39, 2011. (doi:10.4136/ambi-agua.171)

CUMMINS, K. W.; MERRITT, R. W.; ANDRADE, P. C. N. The use of invertebrate functional groups to characterize ecosystem attributes in selected streams and rivers in south Brazil. Studies on Neotropical Fauna and Environment, v. 40, p. 69-89, 2005. http://dx.doi.org/10.1080/01650520400025720

BRINKHURST, R. O.; MARCHESE, M. R. Guia para la identification de Oligoquetos aquaticos continentales de Sud y Centroamerica. Clímax: Santa Fe, 1989. 207 p.

DORNFELD, C. B.; FONSECA-GESSNER, A. A. Fauna de Chironomidae (Diptera) associada à Salvinia sp. e Myriophyllum sp. num reservatório do Córrego do Espraiado, São Carlos, São Paulo, Brasil. Entomologia y Vectores, v. 12, n. 2, p. 181-192, 2005. http://dx.doi.org/10.1590/S0328-03812005000200005

FERNANDEZ, H. R.; DOMINGUEZ, E. Guía para la determinación de los artrópodos bentónicos sudamericanos. Tucumán: Universidad Nacional de Tucumán, Faculdade de Ciencias Naturales e Instituto Miguel Lillo, 2001. 282 p.

FUSARI, L. M.; FONSECA-GESSNER, A. A. Environmental assessment of two small reservoirs in southeastern Brazil, using macroinvertebrate community metrics. Acta Limnologica Brasiliense, v. 18, n. 1, p. 89-99, 2006.

GRAÇA, M. A. S. The role of invertebrates on leaf litter decomposition in stream: a review. International Review of Hydrobiology, v. 86, p. 383-393, 2001. http://dx.doi.org/10.1002/1522-2632(200107)86:4/5\%3C383::AIDIROH383\%3E3.0.CO;2-D

GONÇALVES JR, J. F.; GRAÇA, M. A. S.; CALLISTO, M. Leaf-litter breakdown in 3 streams in temperate, Mediterranean, and tropical Cerrado climates. Journal of the North American Benthological Society, v. 25, p. 344-355, 2006. http://dx.doi.org/10.1899/0887-3593(2006)25[344:LBISIT]2.0.CO;2

HUMPRIES, P. Aquatic macrophytes, macroinvertebrate associations and water levels in a lowland Tasmanian river. Hydrobiologia, v. 321, p. 219-233, 1996. http://dx.doi.org/10.1007/BF00143752

JANKE, H.; TRIVINHO-STRIXINO, S. Colonization of leaf litter by aquatic macroinvertebrates: a study in a low order tropical stream. Acta Limnologica Brasiliense, v. 19, p. 109-179, 2007.

JOLY, A. B. Botânica: introdução à taxonomia vegetal. São Paulo: Nacional, 1998. p. 777.

KURASHOV, E. A.; TELESH, I. V.; PANOV, V. E.; USENKO, N. V.; RYCHKOVA, M. A. Invertebrates communities associated with macrophytes in Lake Ladoga: effects of environmental factors. Hydrobiologia, v. 322, p. 49-55, 1996. http://dx.doi.org/10.1007/BF00031804

LEROY, C. J.; MARKS, J. C. Litter quality, stream characteristics and litter diversity influence decomposition rates and macroinvertebrates. Freshwater Biology, v. 51, p. 605-617, 1996.

http://dx.doi.org/10.1111/j.1365-2427.2006.01512.x

MERRIT, R.; CUMMINS, K. An introduction to the aquatic insects of North America. Dubuque: Kendall Hunt, 1996. 722 p. 
SILVA, F. L.; OLIVEIRA, H. R. N.; ESCARPINATI, S. C.; FONSECA-GESSNER, A. A.; PAULA, M. C. Colonization of leaf litter of two aquatic macrophytes, Mayaca fluviatilis, Aublet and Salvinia auriculata, Aublet by aquatic macroinvertebrates in a tropical reservoir. Ambi-Agua, Taubaté, v. 6, n. 1, p. 30-39, 2011. (doi:10.4136/ambi-agua.171)

MORETTI, M. S.; GOULART, M. D. C.; CALLISTO, M. Avaliação rápida da macrofauna associada à Eichhornia azurea (Swartz) Kunth, 1843 e Pontederia laceolata Nutt., 1818 (Pontederiaceae) na Baía do Coqueiro, Pantanal de Poconé (MT/Brasil). Revista Brasileira de Zoociencias, v. 5, p. 7-21, 2003.

MORETTI, M. S.; GONÇALVES, J. F.; LIGEIRO, R.; CALLISTO, M. Invertebrates colonization on native tree leaves in a neotropical stream (Brazil). International Review of Hydrobiology, v. 92, n. 2, p. 199-210, 2007. http://dx.doi.org/10.1002/iroh.200510957

MORMUL, R. P.; VIEIRA, L. A.; PRESSINATTE JR, S.; MONKOLSKI, A.; SANTOS, A. M. Sucessão de invertebrados durante o processo de decomposição de duas plantas aquáticas (Eichhornia azurea e Polygonum ferrugineum). Acta Scientiarum. Biological Sciences, v. 28, n. 2, p. 109-115, 2006.

STRIPARI, N.; HENRY, R. The invertebrate colonization during decomposition of Eichhornia azurea Kunth in a lateral lake in the mouth zone of Paranapanema river into Jurumirim Reservoir (São Paulo, Brazil). Brazilian Journal of Biology, v. 62, n. 2, p. 293-310, 2002. http://dx.doi.org/10.1590/S1519-69842002000200014

TRIVINHO-STRIXINO, S.; STRIXINO, G. Larvas de Chironomidae (Diptera) do Estado de São Paulo: guia de identificação e diagnose dos gêneros. São Carlos: PPG-ERNUFSCar, 1995a. 227p.

TRIVINHO-STRIXINO, S.; STRIXINO, G. Duas novas espécies de Nimbocera reiss (Diptera: Chironomidae) do estado de São Paulo, Brasil. Revista Brasileira de Entomologia, v. 35, p. 173-178, 1995b.

TRIVINHO-STRIXINO, S.; STRIXINO G. Estrutura da comunidade de insetos aquáticos associados à Pontederia laceolata Nuttal. Revista Brasileira de Biologia, v. 53, n. 1, p. 103-111, 1993.

TRIVINHO-STRIXINO, S.; CORREIA, L. C. S.; SONODA, K. C. Phytophilous Chironomidae (Diptera) and other macroinvertebrates in the ox-bow Infernão Lake (Jataí Ecological Station, Luiz Antônio, SP, Brazil). Revista Brasileira de Biologia, v. 60, n. 3, p. 527-535, 2000.

WARD, J. V. Aquatic insect ecology 1: biology and habitat. New York: John Wiley and Sons, 1992. 438p.

WRIGHT, M. S.; COVICH, A. P. The effect of macroinvertebrate exclusion on leaf breakdown rates in a tropical headwater stream. Biotropica, v. 37, p. 403-408, 2005. http://dx.doi.org/10.1111/j.1744-7429.2005.00053.x 